\title{
Prevention measures for vertical HIV transmission: monitoring infected pregnant women and exposed children
}

Cristina Silvana da Silva Vasconcelos 1

iD https://orcid.org/0000-0002-5512-5826

Renata Junqueira Pereira 2

iD https://orcid.org/0000-0001-9487-4013

Adiléia Fernandes Barros da Silva Santos 3

(iD https://orcid.org/0000-0001-9750-2784

Lúcia Helena Almeida Gratão 4

iD https://orcid.org/0000-0001-5817-5784

\footnotetext{
1.3 Programa de Residência Multiprofissional em Saúde Coletiva. Fundação Escola de Saúde Pública de Palmas. Palmas, TO, Brasil.

2 Departamento de Nutrição. Universidade Federal do Tocantins. Palmas, TO, Brasil.

${ }^{4}$ Departamento de Pediatria. Faculdade de Medicina. Universidade Federal de Minas Gerais. Av. Prof. Alfredo Balena, 190. Santa Efigênia. Belo Horizonte, MG, Brasil. CEP 30130-100. E-mail: luciagratao@gmail.com
}

\begin{abstract}
Objectives: to present an analysis of the follow-up of exposed children and pregnant women living with HIV who are assisted in a reference public healthcare service of a Brazilian capital.

Methods: this is a cross-sectional study with sociodemographic and clinical data obtained from physical and electronic medical records of women living with HIV and exposed children, treated between 2000 and 2018, in a secondary healthcare service. For associations, the chi-square test at 5\% significance was used.

Results: the data about 183 pregnancies and 214 children from the capital or other municipalities in the state were analyzed. The women have low schooling, are brown or black, single, multiparous, diagnosed with HIV during prenatal care, with the start of follow-up from the third trimester of pregnancy and the use of prophylaxis during childbirth. As for children, the associations were significant for notification on SINAN, admission to the health service, use of prophylaxis indicating better monitoring for those who live in the state capital.

Conclusions: the prevention measures recommended by the Ministry of Health, in general, were followed, but children and pregnant women who live in other cities were worse off than those ones in the capital. Unnotified cases were identified on SINAN. These issues may contribute to new cases of vertical transmission of HIV.
\end{abstract}

Key words Vertical transmission of infectious disease, HIV, Maternal health, Child health, Public health, Health services 


\section{Introduction}

The epidemiological scenario of infection by the Human Immunodeficiency Virus (HIV) shows a high number of cases in women of childbearing age, with a $38.1 \%$ increase in the detection rate for pregnant women living with HIV in the last ten years. ${ }^{1}$ It is observed that more than $86.2 \%$ of cases of infected children under the age of thirteen occurred during pregnancy, at the time of delivery or by breastfeeding, an event clinically called vertical transmission (HIV-VT). 2

In order to monitor seroreversion, it is recommended that every child exposed to the virus be followed for 18 months from birth by the referral service. ${ }^{2}$ During this period, it is advisable to carry out at least two molecular tests of viral load (CVHIV) and to perform anti-HIV serology before discharge, so that only then the case is, in fact, closed. 3 Oliveira et al. 4 confirm that providing adequate follow-up and starting antiretroviral treatment in a timely manner are protective factors that can contribute to reducing the possibility of HIV-VT and seroconversion in children.

Considering the objective of epidemiological surveillance to monitor the behavior of HIV/AIDS, 5 it is essential to monitor the care of children exposed to HIV in the Health Care and Surveillance Networks (Redes de Atenção e Vigilância em Saúde - RAVS), as well as in all available health devices to keep the child assisted and safe. To this purpose, epidemiological surveillance uses data provided by reference services, which are useful for planning, evaluating and improving actions for promotion, prevention and control.6,7

It is hypothesized that there are children exposed to HIV who were not followed up as recommended by the Ministry of Health and did not perform the CV-HIV, CD4 and anti-HIV serology tests in the capital and that the record of this monitoring is worse with children residing in other municipalities. In addition to characterizing the sociodemographic and clinical profile, the present study seeks to present an analysis of the monitoring of exposed children and pregnant women living with HIV treated at a public service of reference in a Brazilian capital.

\section{Methods}

This is a cross-sectional study conducted in Palmas, capital of the state of Tocantins, located in the northern region of Brazil, in a public reference healthcare service for people living with HIV
(SPA/HIV). The SPA/HIV is a member of RAVS, managed by the Secondary Health Care team of the Municipal Health Department, operating since 2000. This service assists people residing in the capital or in other municipalities in the state. The project for carrying out this study was approved by the Research Ethics Committee (CEP - Portuguese acronym) of the Federal University of Tocantins (UFT) under number 1,618,415.

Characterization and analysis of sociodemographic and clinical data of all children exposed to the virus, by vertical transmission and of pregnant women living with HIV, attended from 2000 to 2018 at the SPA/HIV was carried out. In order to identify all pregnancies and children attended at the service, an individual analysis of all physical and electronic medical records (E-SUS) was performed.

The databases of the Disease Notification System (SINAN) and the Laboratory Examination Control System (Sistema de Controle de Exames Laboratoriais - SISCEL) were also used. They were necessary to consult divergent or missing information in the medical records, such as notification, use of prophylaxis during pregnancy, labor and delivery and results of molecular tests. Medical records of pregnant women and children who did not have their place of residence were excluded.

The HIV-VT prevention measures recommended by the Ministry of Health were considered: i) testing for HIV and other Sexually Transmitted Infections (STIs) in prenatal care (first and third trimester); ii) use of prophylactic antiretroviral therapy before and during pregnancy and at birth; iii) cesarean section for women with unknown viral load (VL-HIV) or above 1,000 copies/mL; iv) replacement of breast milk with milk formula; v) use of zidovudine and other drugs to prevent pneumonia by the newborn (NB)2 and; vi) notification of all cases in the Information System for Notifiable Diseases (Sistema de Informação e Agravos de Notificação - SINAN), mandatory since 2000.8

The variables collected, related to pregnant women, were: municipality of residence, education, self-declared color, marital status, number of pregnancies, diagnosis of HIV infection, admission to the SPA/HIV, use of prophylaxis during pregnancy, use of prophylaxis during labor and delivery and confirmation of pregnancy notification on SINAN.

The variables related to children were: sex, admission to the HIV-SPA, use of prophylaxis during pregnancy by the mother, use of prophylaxis by the child, carrying out a molecular test (viral load), carrying out anti-HIV serology after 18 months, recording of seroreversion, departure from the SPA- 
HIV and confirmation of the notification as a child exposed on SINAN.

The performance of a molecular test (viral load) was analyzed according to the number of tests performed, classified in: no test performed ' 0 ', one test performed ' 1 ' or two or more tests performed ' $\geq$ 2'.

The frequencies of medical records that did not have the desired information were kept as "No Information' in order to demonstrate the non-filling of the fields or the non-registration of the monitoring offered in the Reference Service.

Thus, 214 medical records of exposed children and 318 medical records of women living with HIV were analyzed, who presented some report of pregnancy monitoring at the service. However, 175 medical records of women were excluded, for reasons such as transfer of treatment unit, abandonment or loss of follow-up at some point during pregnancy and failure to terminate pregnancy due to abortion or other causes.

For the characterization of the sample, the Shapiro-Wilk and Kalimogorov-Smirnov normality tests were used. The variables were described by frequencies, measures of central tendency and measures of dispersion. To compare proportions between the municipality of Palmas-TO, other municipalities served and the other study variables, the chi-square association test $\left(\chi^{2}\right)$ was applied, with $5 \%$ significance level.

The construction of the database was performed with the aid of the Excel program (Microsoft Corp., United States), and the data analyzes were processed using the SPSS 15.0 program (SPSS Inc., United States).

\section{Results}

Physical and electronic medical records of 183 pregnancies of 150 women and 214 children exposed to HIV infection were analyzed. The sociodemographic and health characteristics of the pregnant women are shown in Table 1.

It is observed that $48.3 \%$ of pregnant women were diagnosed with HIV during prenatal care, $32.2 \%$ started follow-up only in the third trimester of pregnancy, $90.2 \%$ used prophylaxis during prenatal care and $64.5 \%$ during delivery, and $29.5 \%$ of the medical records did not have this information. Regarding notification on SINAN, only $80.3 \%$ of cases were notified (Table 1 ).

Table 2 describes the health characteristics of children exposed to HIV vertically and the results of statistical tests comparing children living in the city of Palmas - TO and children living in other cities served by the SPA/HIV.

In Palmas - TO, there was a significantly higher number of children who arrived at the specialized service within 30 days after discharge from maternity, compared to children from other municipalities $(p<0.001)$. Regarding notification on SINAN, $40.0 \%$ of children living in other municipalities did not have any information about notification on SINAN, while in the capital, $10.1 \%$ did not have information $(p<0.001)$.

The comparison of women who used prophylaxis (ARV) during childbirth, showed the use in $60.4 \%$ of pregnant women living in Palmas - TO, and in only $47.7 \%$ of those from other municipalities ( $p=$ 0.218 ). The use of prophylaxis (AZT) by children was reported for $81.2 \%$ of residents in Palmas - TO and $61.5 \%$ of those from other municipalities ( $p=$ $0.003)$. In both variables, the number of medical records without information was higher in children from other municipalities $(32.3 \%)$ compared to Palmas (29.2\%).

High occurrence of medical records without information regarding the performance of anti-HIV serology after 18 months and documentation of seroreversion stands out both in children living in Palmas - TO and in other municipalities.

There was no significant difference between the number of children with seroreversion, when comparing residents in the capital to other municipalities $(p=0.131)$. Likewise, there was no statistically significant difference between the percentages of children who left the service due to discharge ( $p=$ 0.644 ) or who were absent from this information

\section{Discussion}

The results show a worse scenario for exposed children and pregnant women living with HIV treated at the SPA/HIV, living in other cities compared to those ones living in the capital. There is a significant number of unreported pregnant women and children and important information that are not available in the medical records.

Similar to other studies, 1,9 it was found that the majority of pregnant women attended at the SPAHIV had low education and declared themselves to be brown. The average number of pregnancies per woman was twice as high as the national number of children.10 Regarding color, the findings of this study followed the state and national distributions. 1,11

The management of HIV-VT prevention is influenced by sociodemographic factors as they may or 
Table 1

Sociodemographic and clinical characteristics of pregnant women living with HIV.

\begin{tabular}{|c|c|c|}
\hline Variables & $\mathbf{N}$ & $\%$ \\
\hline \multicolumn{3}{|l|}{ Municipality of residence } \\
\hline Palmas & 114 & 62.3 \\
\hline Others & 69 & 37.7 \\
\hline \multicolumn{3}{|l|}{ Education } \\
\hline Illiterate & 1 & 0.5 \\
\hline Incomplete elementary school & 59 & 32.2 \\
\hline Complete primary education & 25 & 13.7 \\
\hline Incomplete high school & 26 & 14.2 \\
\hline Complete high school & 56 & 30.6 \\
\hline Incomplete higher education & 7 & 3.8 \\
\hline Complete higher education & 5 & 2.7 \\
\hline No information & 4 & 2.2 \\
\hline \multicolumn{3}{|l|}{ Self-declared color of skin } \\
\hline White & 28 & 15.3 \\
\hline Black & 42 & 23.0 \\
\hline Mixed & 110 & 60.1 \\
\hline No information & 3 & 1.6 \\
\hline \multicolumn{3}{|l|}{ Marital status } \\
\hline Married & 64 & 35.0 \\
\hline Single & 75 & 41.0 \\
\hline Stable union & 39 & 21.3 \\
\hline Widowed & 2 & 1.1 \\
\hline No information & 3 & 1.6 \\
\hline \multicolumn{3}{|l|}{ Number of pregnancies a } \\
\hline Up to two & 65 & 45.5 \\
\hline Three or more & 76 & 52.5 \\
\hline No information & 3 & 1.6 \\
\hline$\overline{\mathrm{X}}(\mathrm{SD})$ & $2.0(2.067)$ & \\
\hline \multicolumn{3}{|l|}{ Diagnosis of HIV infection b } \\
\hline Before prenatal care & 63 & 44.1 \\
\hline During prenatal care & 69 & 48.3 \\
\hline Childbirth & 5 & 3.5 \\
\hline No information & 6 & 4.1 \\
\hline \multicolumn{3}{|c|}{ Admission to the reference health service } \\
\hline First trimester & 29 & 15.8 \\
\hline Second trimester & 47 & 25.7 \\
\hline Third trimester & 59 & 32.2 \\
\hline No information & 48 & 26.2 \\
\hline \multicolumn{3}{|c|}{ Use of prophylaxis (ARV) during pregnancy } \\
\hline During prenatal care & 165 & 90.2 \\
\hline Only in delivery & 2 & 1.1 \\
\hline Not used & 5 & 2.7 \\
\hline No information & 11 & 6.0 \\
\hline
\end{tabular}

continue

a Data regarding the last pregnancy followed up at the service; $b$ Data regarding the first pregnancy of the pregnant woman monitored at the service; HIV = Human Immunodeficiency Virus; ARV = Antiretroviral; SINAN = Sistema de Informação de Agravos de Notificação; AF = Absolute Frequency; RF = Relative Frequency; N = Sampling; SD = Standard Deviation. 
Sociodemographic and clinical characteristics of pregnant women living with HIV.

\begin{tabular}{lcc}
\hline Variables & N & $\%$ \\
\hline Use of prophylaxis (ARV) during delivery & & 64.5 \\
Used & 118 & 6.0 \\
Not used & 11 & 29.5 \\
No information & 54 & 80.3 \\
Notification of pregnancy at SINAN & 147 & 19.1 \\
Yes & 35 & 0.5 \\
No & 1 & \\
Not information & &
\end{tabular}

a Data regarding the last pregnancy followed up at the service; b Data regarding the first pregnancy of the pregnant woman monitored at the service; HIV = Human Immunodeficiency Virus; ARV = Antiretroviral; SINAN = Sistema de Informação de Agravos de Notificação; $\mathrm{AF}=$ Absolute Frequency; RF = Relative Frequency; $\mathbf{N}=$ Sampling; SD = Standard Deviation.

Table 2

Clinical characteristics of children exposed to HIV accompanied by a secondary care service in Palmas, Tocantins, 20002018. ( $n=214$ children).

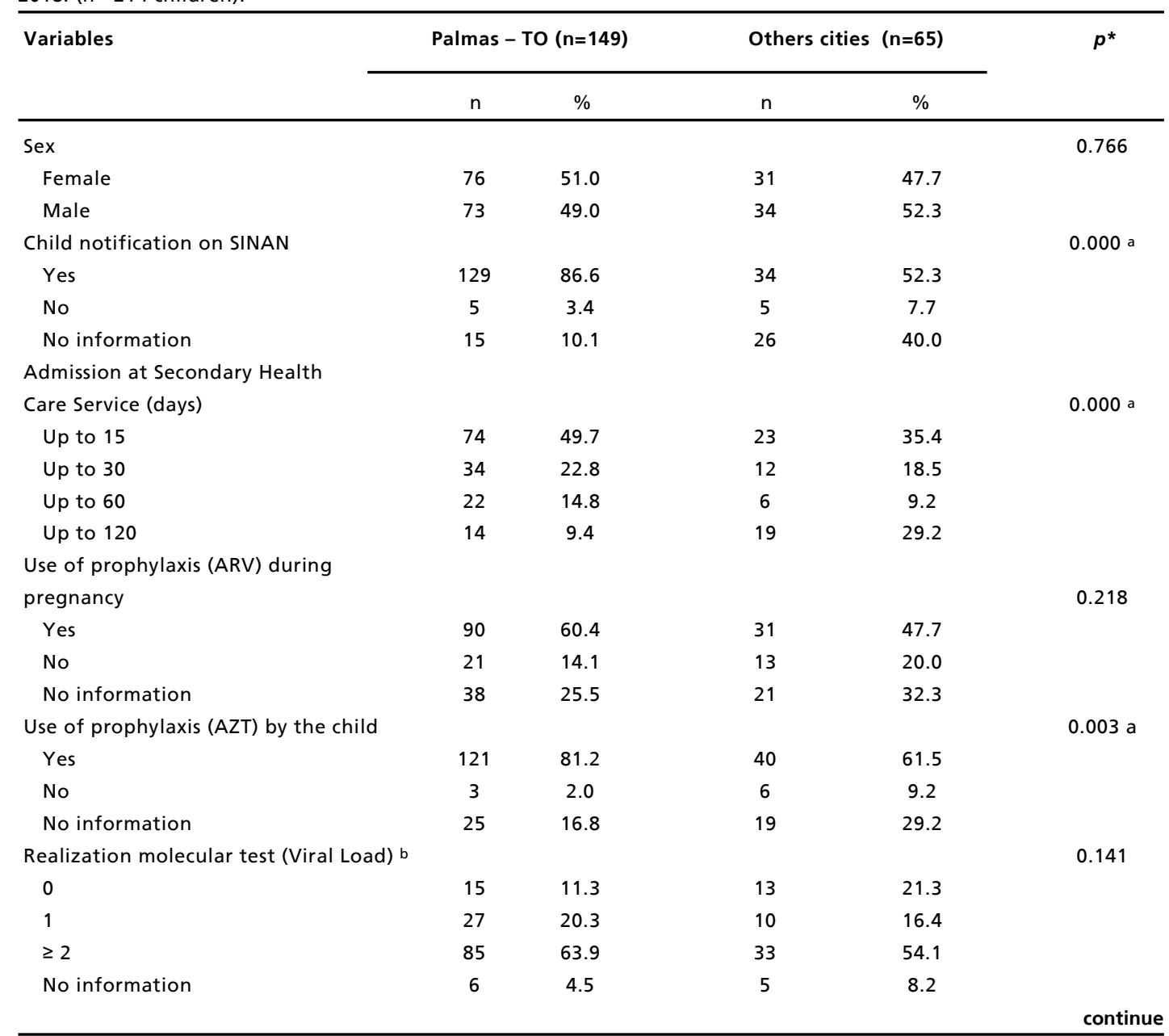

a Significant by the Chi-square test, at $5 \%$ significance; b Data about children who completed 18 months $(n=194)$; cDeath or transfer; HIV = Human Immunodeficiency Virus; ARV =Antiretroviral; AZT = azidothymidine; SINAN = Sistema de Informação de Agravos de Notificação; $\mathrm{n}$ = Sampling; SD = Standard Deviation; *Chi-square. 
Clinical characteristics of children exposed to HIV accompanied by a secondary care service in Palmas, Tocantins, 20002018. ( $n=214$ children).

\begin{tabular}{|c|c|c|c|c|c|}
\hline \multirow[t]{2}{*}{ Variables } & \multicolumn{2}{|c|}{ Palmas - TO $(n=149)$} & \multicolumn{2}{|c|}{ Others cities $(n=65)$} & \multirow[t]{2}{*}{$p^{*}$} \\
\hline & $\mathrm{n}$ & $\%$ & $\mathrm{n}$ & $\%$ & \\
\hline \multicolumn{6}{|c|}{ Realization serology HIV after } \\
\hline 18 months b & & & & & 0.290 \\
\hline Yes & 28 & 21.1 & 19 & 31.1 & \\
\hline No & 29 & 21.8 & 13 & 21.3 & \\
\hline No information & 76 & 57.1 & 29 & 47.5 & \\
\hline Seroreversion b & & & & & 0.131 \\
\hline Yes & 23 & 17.3 & 12 & 19.7 & \\
\hline No & 5 & 3.8 & 7 & 11.5 & \\
\hline No information & 105 & 78.9 & 42 & 68.9 & \\
\hline \multicolumn{6}{|c|}{ Departure from the Secondary Health } \\
\hline Care Service b & & & & & 0.644 \\
\hline Discharge & 67 & 50.4 & 29 & 47.5 & \\
\hline Others reasons c & 29 & 21.8 & 17 & 27.9 & \\
\hline No information & 37 & 27.8 & 15 & 24.6 & \\
\hline
\end{tabular}

a a Significant by the Chi-square test, at $5 \%$ significance; b Data about children who completed 18 months ( $\mathrm{n}=194)$; cDeath or transfer; HIV = Human Immunodeficiency Virus; ARV =Antiretroviral; AZT = azidothymidine; SINAN = Sistema de Informação de Agravos de Notificação; $\mathrm{n}$ = Sampling; SD = Standard Deviation; *Chi-square.

may not favor adherence to antiretroviral treatment, adequate prophylaxis and monitoring of VL-HIVprotective factors for children.2,12,13 Studies point out that aspects such as high number of children, low education and race/brown or black color can be markers of vulnerability with regard to the quality of prenatal care and childbirth and access to health information and services, negatively influencing the adherence to follow-up of the child exposed to the virus. $13,14,15$

Most pregnant women reported being single, but $56.3 \%$ reported being married or in a stable relationship. Depending on the quality of the relationship and acceptance of serology, having a partner can be a facilitator in the continuity of care for the child. 14 Thinking of the support arising from affective relationships, in a study by Faria et al.16 in Porto Alegre - RS, emotional support was found as a variable associated with undetectable CV-HIV in pregnancy. Pregnant women with greater emotional support were 2.55 times more likely to adhere to treatment. The authors 16 emphasize that emotional support, as an aspect of social support, is an important facilitator of treatment adherence in pregnant women, as it involves the availability of listening, attention, information and support for anxiety in the face of fear of the baby's infection and the disclosure of the diagnosis to the family.
In the present study, most pregnant women were diagnosed during prenatal care, started to follow up at the reference service only in the third trimester of pregnancy and some of them did not have information on admission to the service. With these results and considering the recommendation regarding the screening of HIV in the first and third trimester of pregnancy, ${ }^{17}$ it is questioned the fragility in the offer and performance of anti-HIV serology in the first trimester of pregnancy, and also the lack of adherence or late start of the prenatal in Primary Care, which should be the guiding principle of care in these cases, in addition to highlighting the weakness of monitoring in health services in the region analyzed.

Furthermore, when considering that $44.1 \%$ were diagnosed before pregnancy, the reason for the time difference between knowledge of serology and admission to the secondary care service is questioned, considering that for many, it occurred only in the third trimester of pregnancy, understood as a loss of opportunity for HIV-VT prevention.

Studies indicate that pregnant women who are adequately monitored and adhere to prenatal care tend to have greater adherence to antiretroviral therapy, mainly because they express greater concern for the health of the newborn, and for having greater access to educational activities 
offered by health services care of professionals. ${ }^{16,18}$ Health actions that provide guidance on the benefits of ART and discuss its impact on the child's health are essential in maintaining monitoring both during pregnancy and after the child's birth, as highlighted by the Ministry of Health. ${ }^{2}$

When analyzing the risk factors for seroconversion of HIV infection in live births, Faria et al.16 found a significant association between breastfeeding and non-use of antiretrovirals during pregnancy with HIV-VT, and all mothers of children living with HIV had detectable and high VL-HIV at delivery, representing a greater risk of vertical transmission. In the present study, insufficient records were found in the medical records that could evidence the practice of breastfeeding and the prophylactic measures offered to pregnant women. However, it was observed that most women used antiretroviral therapy during pregnancy and during birth, a considerable factor, since the literature points to an association between therapy during pregnancy and labor, and delivery with seroreversion in children. 4

According to a specific protocol, 2 the risk of HIV-VT is determined by maternal VL-HIV, by not using antiretroviral therapy during pregnancy and by the relation between the time of effective antiretroviral therapy and birth. It is also noteworthy that women with elevated VL-HIV and who do not have adequate follow-up, have an indication for cesarean section, which increases the chances of surgical complications, risk of infection and longer hospital stay. 19

Regarding compulsory notification, it is expected that the number of notifications made during prenatal care, conducted by Primary Care, will be higher than those made in the secondary care service and in the maternity ward, as this points to efforts to early captation pregnant women and possibility of timely initiation of appropriate preventive measures. The contrary may suggest weakness in the quality of prenatal care, failures in training and in recognition by health professionals of the importance of compulsory notification.7 In this study, although more than half of the cases have been reported, the results have not yet been reported satisfactorily, since $19.1 \%$ of pregnant women who were followed up at the reference service were not notified on SINAN.

The notification of the exposed child must be made at the maternity hospital shortly after birth. 3 Most children who live in the capital of Tocantins and in other municipalities were notified; however, information from $40 \%$ of residents in other munici- palities was absent and it was identified that $7.7 \%$ were not notified. Such underreporting is important and may suggest lack of access to notifications from children living in other municipalities through the technical area of Palmas - TO, in addition to showing the occurrence of underreporting in municipalities in the interior, exposing such patients to a higher risk of HIV-VT.

The protocol emphasizes that discharge from the maternity hospital must be accompanied by an appointment scheduled at a secondary care service for the follow-up of the children, not exceeding fifteen days after birth and, in case of no-show, it is necessary to contact the mother through an active search. 3 Monitoring of children at the SPA/HIV should be monthly for the first six months and at least every two months from one year to eighteen months of life. The first VL should be collected two weeks after the end of prophylaxis (AZT) and the second after six weeks. 3

In the present study, the children had their first consultation at the service within 30 days. Children from other municipalities were admitted later to the SPA-HIV, compared to residents in the capital, since $29.2 \%$ arrived at the service within 120 days after birth. Macedo et al.20 point out that the early entry into the service may be related to the caregivers' concern with the health of the newborn, but it does not mean greater adherence to the child's follow-up, since it depends on social and economic factors, professional-patient relationship and the caregiver's understanding of the importance of monitoring.

Regarding the use of prophylaxis by the mother and the child, this study corroborates the findings of other studies 21,22 in which most mothers and children used it. On the other hand, data from patients who did not receive AZT, from mothers who did not use prophylaxis during pregnancy or from medical records with missing information, represent a risk of undocumented vertical transmission, loss of followup and underreporting in the municipalities served by SPA-HIV.

In this context, the importance of reference and counter-reference between maternity, primary care and secondary care - partners in the active search for cases, a strategy used in public health that involves differentiated care of health professionals with the patient is highlighted. Respecting ethical principles, the bond with people living with HIV can be strengthened, decreasing the abandonment rate and minimizing losses to follow-up, which interfere with seroreversion. 20

More than half of children in the capital (58.4\%) and in other municipalities $(50.8 \%)$ underwent more 
than two VL-HIV tests. Similar data were found in other studies, 13 indicating the number of exams recommended by the Ministry of Health protocol. ${ }^{3}$ However, $37.7 \%$ and $31.6 \%$ of children residing in Palmas - TO and in other municipalities, respectively, did not perform the minimum number of VLHIV exams, implying the monitoring and closing of cases. It is noteworthy that the distance between the SPA-HIV and the municipality of residence can be an existing problem in carrying out the exams, in the term and in the proper monitoring of the children.

There were few records on the performance of HIV serology, on seroreversion and on the exit of the SPA-HIV in the medical records, both of children living in the capital, as well as in the interior. It is assumed that this is due to the fact that the diagnosis is closed only with VL-HIV tests and because the ministerial protocol recommends that serology be performed after 18 months only in order to document the case, 3 that is, it is not mandatory to close the diagnosis. In relation to leaving the service, there is no way to ensure that the discharge occurred with the performance of serology or not, as the discharge information is not properly qualified, specifying only in cases of death and transfer.

It is noteworthy that the fields of the mother's epidemiological background, investigation of the child exposed to HIV and the evolution of the case are present only in the physical notification form, 7 which does not make these fields mandatory for closing the case on SINAN, making it difficult to obtain information and demanding that professionals search for data in internal health service documents, in other information systems or directly with the epidemiological surveillance boards.

In general, from the descriptive analysis of the data, it can be said that the HIV-VT prevention measures instituted in the Ministry of Health protocol were followed in most cases attended by the SPA-HIV, however, important weaknesses were found in the care offered to the child and the pregnant woman and that could contribute to new cases of vertical transmission of HIV, that is, possible weakness in the offer and performance of anti-HIV serology in the first trimester of pregnancy and the lack of adherence or late onset of prenatal in Primary Care; considerable time difference between knowledge of serology and admission to the secondary care service; late admission of children from other municipalities to the SPA-HIV in relation to those who lived in the capital; scarcity of records about HIV serology, about seroreversion, breastfeeding and about leaving the SPA-HIV in the medical records of both children living in the capital and in the countryside.

In view of the results, in order to improve communication between the levels of care, it is suggested that a technical group be created with periodic meetings to discuss cases between representatives of the Maternity Hospital, reference Primary Care team, secondary care service and technical area of epidemiological surveillance in the capital and other municipalities. In addition, it is highlighted the importance of i) early captation of pregnant women living with HIV for prenatal care and for follow-up at the SPA-HIV; ii) active search for cases, mainly of residents in cities in the countryside promoting active dialogues between managers of the partner cities and iii) investment in training professionals on the use of health information and on the importance of keeping patients' clinical records up to date for surveillance and investigation of cases.

The limitations of this study include obtaining information from secondary data sources, which, as noted in this and other studies, are fragile and are not always filled in properly. However, there are potentialities, since it is the first study in the state of Tocantins that evaluates and discusses the monitoring of exposed children and pregnant women living with HIV/AIDS. In addition, there is a sample made up of $100 \%$ of individuals treated at the SPA/ HIV, with a period of 18 years.

\section{Authors' contribution}

Vasconcelos, CSS and Gratão, LHA were responsible for conception and design of the work; data acquisition, analysis and interpretation; and elaboration of intellectual content. Santos, AFBS was responsible for data acquisition, analysis and interpretation. Pereira, RJ was responsible for development of intellectual content. All authors approved the final version of the article. 


\section{References}

1. Brasil. Ministério da Saúde. Secretaria de Vigilância em Saúde. Departamento de Vigilância, Prevenção e Controle das Infecções Sexualmente Transmissíveis, do HIV/Aids e das Hepatites Virais. Boletim Epidemiológico HIV e Aids. Brasília, DF; 2019. Disponível em: http://www.aids.gov.br/ system/tdf/pub/2016/67064/boletim_hivaids_2019.pdf?file $=1 \&$ type $=$ node $\&$ id $=67064 \&$ force $=1$

2. Brasil. Ministério da Saúde. Secretaria de Vigilância em Saúde. Departamento de Doenças de Condições Crônicas e Infecções Sexualmente Transmissíveis. Protocolo Clínico e Diretrizes Terapêuticas para Prevenção da Transmissão Vertical do HIV, Sífilis e Hepatites Virais. Brasília, DF; 2019. Disponível em: http://www.aids.gov.br/system/tdf/ pub/2016/57801/miolo_pcdt_tv_08_2019.pdf?file=1\&type $=$ node $\&$ id $=57801 \&$ force $=$

3. Brasil. Ministério da Saúde. Secretaria de Vigilância em Saúde. Departamento de Vigilância, Prevenção e Controle das Infecções Sexualmente Transmissíveis, do HIV/Aids e das Hepatites Virais. Protocolo Clínico e Diretrizes Terapêuticas para Manejo da Infecção pelo HIV em Crianças e Adolescentes. Brasília, DF; 2018. Disponível em: http://www.aids.gov.br/system/tdf/pub/2016/64833/ pcdt_infantil_04_2019_web.pdf?file $=1 \&$ type $=$ node\&id $=64$ $833 \&$ force $=1$

4. Oliveira KWK, Oliveira SK, Barranco ABS, Hoffmann T, Duarte CS, Nazário RF, Marcon CEM, Schuelter-Trevisol F. Transmissão vertical do HIV na Região Sul de Santa Catarina, 2005-2015: análise dos fatores de risco para soroconversão em nascidos vivos. Rev Bras Saúde Mater Infant. 2018; 18 (3): 471-9.

5. Brasil. Ministério da Saúde. Secretaria de Vigilância em Saúde. Coordenação-Geral de Desenvolvimento da Epidemiologia em Serviços. Guia de Vigilância em Saúde: volume único [recurso eletrônico]. Brasília, DF; 2019. Disponível em: https://portalarquivos2.saude.gov.br/ images/pdf/2019/junho/25/guia-vigilancia-saude-volumeunico-3ed.pdf

6. Lima DJM, Chagas ACMA, Mendes IC, Oriá MOB, Aquino PS, Pinheiro AKB. Completude e consistência dos dados de gestantes HIV positivas notificadas. Rev Enferm UERJ. 2014; 22 (3): 321-6.

7. Meirelles MQB, Lopes AKB, Lima KC. Vigilância epidemiológica de HIV/Aids em gestantes: uma avaliação acerca da qualidade da informação disponível. Rev Panam Salud Publica. 2016; 40 (6): 427-34.

8. Portaria de consolidação $\mathrm{n}^{\circ} 4$, de 28 de setembro de 2017 . Consolidação das normas sobre os sistemas e os subsistemas do Sistema Único de Saúde. Disponível em: http://bvsms.saude.gov.br/bvs/saudelegis/gm/2017/prc0004 03_10_2017.html

9. Bick MA, Ferreira T, Sampaio CO, Padoin SMM, Paula CC. Perfil de gestantes infectadas e crianças expostas ao HIV atendidas em serviço especializado do sul do Brasil. Rev Bras Saúde Mater Infant. 2018; 18 (4): 803-13.

10. UNPA (Fundo de População das Nações Unidas).

Received on May 14, 2020

Final version presented on 16 November 2020

Approved on December 3, 2020
Fecundidade e Dinâmica da População Brasileira. Brasília, DF; 2018. Disponível em: https://brazil.unfpa.org/sites/ default/files/pub-pdf/sumario_executivo_br_0.pdf

11. Tocantins. Secretaria do Planejamento e Orçamento. Indicadores socioeconômicos do Estado do Tocantins. 2017. Disponível em: https://central3.to.gov.br/arquivo/ $349157 /$

12. Souza HCS, Mota MR, Alves AR, Lima FD, Chaves SN, Dantas ERA, Abdelmur SBM, Mota APVS. Análise da adesão ao tratamento com antirretrovirais em pacientes com HIV/AIDS. Rev Bras Enferm. 2019; 72 (5): 1361-9.

13. Galvão MTG, Cunha GHC, Freitas JG, Gir E, Reis RK. Condições sociodemográfica, materna e clínica de crianças expostas ao vírus da imunodeficiência humana. Rev Rene. 2014; 15 (1): 78-88

14. Torres RR, Ferreira LC, Santos TC, Santos AP, Oliveira VPG. Adesão da genitora vivendo com HIV/Aids no acompanhamento da sororreversão do filho. J Health Connections. 2017; 1 (1): 19-32.

15. Leal MC, Gama SGN, Pereira APE, Pacheco VE, Carmo CN, Santos RV. A cor da dor: iniquidades raciais na atenção pré-natal e ao parto no Brasil. Cad Saúde Pública. 2017; 33 (1): 1-17.

16. Faria ER, Carvalho FT, Lopes RS, Piccinini CA, Gonçalves TR, Santos BR. Gestação e HIV: Preditores da adesão ao tratamento no contexto do pré-natal. Psic Teor e Pesq. 2014; 30 (2): 197-203.

17. Brasil. Sociedade Beneficente Israelita Brasileira Albert Einstein. Nota técnica para organização da rede de atenção à saúde com foco na atenção primária à saúde e na atenção ambulatorial especializada - saúde da mulher na gestação, parto e puerpério. São Paulo: Hospital Israelita Albert Einstein: Ministério da Saúde; 2019. Disponível em: https://atencaobasica.saude.rs.gov.br/upload/arquivos/2020 01/03091259-nt-gestante-planificasus.pdf

18. Carvalho MO, Figueiredo MN, Rolemberg AS, Silva JRS, Soares AF. Sororreversão de crianças expostas ao vírus da imunodeficiência humana. Braz J Hea Rev. 2019; 2 (4): 3265-82.

19. OMS (Organização Mundial da Saúde). Declaração da OMS sobre Taxas de Cesáreas. Genebra: OMS, 2015 [citado 11 nov. 2020]. Disponível em: https://apps.who.int/iris/bitstream/handle/10665/161442/W HO_RHR_15.02_por.pdf? sequence $=3$

20. Macedo MR, Frauches DO, Macedo LR, Macedo CR Crianças expostas à transmissão vertical do HIV: seguimento incompleto e sua possível implicação no desfecho. Rev Bras Pesq Saúde. 2013; 15 (2): 73-80

21. Burg MR, Andreazza M, Silva SR, Oliveira MMT, Santos S, Raffo N. Acompanhamento de crianças expostas ao HIV materno no município de Canoas/RS. Rev Enferm UFSM. 2017; 7 (2): 248-61.

22. Miranda AE, Pereira GFM, Araujo MAL, Silveira MF, Tavares LL, Silva LCF, Moreira-Silva SF, Saraceni V. Avaliação da cascata de cuidado na prevenção da transmissão vertical do HIV no Brasil. Cad Saúde Pública. 2016; 32 (9): 1-10. 